\title{
Възможностите на консервативното лечение на корозивните стриктури на хранопровода
}

\author{
Ц. Цолов \\ Катедра УНГ при МУ - София, база УМБАЛ „Царица Йоанна - София“
}

\section{Резюме}

Със съжаление трябва да отбележим, че по честота на изгарянията на хранопровода при деца и възрастни с корозивни средства сме на едно от пьрвите места в Европа. Заболяването се характеризира с две коренно различни фази - остра и хронична, като има твърде съществени различия при лечебните мероприятия в двете фази.

Желателно е децата с изгаряния на хранопровода да попаднат незабавно в клиниките по детска хирургия или в токсикологични (реанимационни) звена, а не в общи детски или УНГ отделения където няма материален и щатен ресурс за такова тежко състояние. Същото важи и за възрастните пациенти, които нерядко се оставят да лежат в УНГ или вътрешни отделения вместо да се насочат към токсикологични или реанимационни звена. След 15 ден от изгарянето, при правилно приложено лечение, пациентът вече следва да се насочи за консултация, в специализирана УНГ клиника, където да се прецени дали пациентът е подходящ за консервативно лечение - бужиране на хранопровода. $\longrightarrow$ ъс съжаление трябва да се отбележи, че по отношение на честотата на изгарянията на хранопровода с киселини и основи, или други каустични средства, нашата страна е на едно от първите места в Европа. Острите и хроничните езофагити са проблем с много неизвестни, като особено сыществени различия се наблюдават по отношение поведението на лекаря и прилаганата терапия в двете фази на заболяването $(1,2,3)$.

Тежестта на патологичният процес, липсата на ефективни методи за лечение на болните с химически изгаряния на хранопровода и последващите в болшинството от случаите ръбцови стриктури на хипофаринкса, хранопровода, стомаха и дванадесетопръстника, придружени с висок леталитет, са ангажирвали вниманието на известни учени - още от Vesalii и Garvei през 16 - 17 век, първи описали това заболяване (2). Известни са системните проучвания извършени от Billrot - описал 524 пациенти с това заболяване (1887 г.), Hacker - 477 болни (1896 г.), Bocay (1924 г.) - 2077 болни, Belasz (1934 г.) - 2 134 болни (2). В България това заболяване за първи път основно е проучено от проф. Ст. Белинов (1936 г.) (1). Според статистиката му за периода 1929 - 1940 г. в 91\% от случаите се е касаело за отравяне със сода каустик и само в 9\% - с киселини или други химически вещества (7). Нашите наблюдения за последните 25 години не показват особена динамика в това отношение - в 90\% от случаите причина е сода каустик и само в 10\% - киселини или други химически агенти (7). При децата това съотношение в общи линии се запазва в $86 \%$ от случаите сода 
каустик и в $14 \%$ - киселини и други химикали (5). По отношение на пола $-30 \%$ са деца, $15 \%$ мъже и 55\% - жени. При жените в 98\% от случаите става въпрос за опит за суицидиум, а при останалите пациенти се касае за прояви на ниска битова култура, неправилно ползване и съхранение на нови химически препарати, навлизащи в ежедневния живот, особено такива за почистване на подове, санитарни възли и пр. (7). Разбира се, в литературата се срещат и съобщения за единични случаи на необичайно изгаряне на хранопровода, напр. от капка разтопен метал, пръснала от металургична пещ (2). Проведените задълбочени изследвания в Токсикологичното отделение на Институтската болница в гр. Плевен, район типичен за този вид заболявания, за периода 1995-1996 г. върху постьпилите 530 пациенти с различни интоксикации, показва, че $13,96 \%$ от тях са с корозивни изгаряния на хранопровода. Почва да се забелязва тенденция към изравняване на половете. Запазват се и причините, довели до тези инциденти. Показателно в това изследване е, че най-много корозивни изгаряния има сред безработните и пенсионерите - общо в $85,1 \%$ от наблюдаваните случаи, което показва, че най-вероятно психосоциалният момент, породен от тежките битови условия, има значителен дял в тази промяна (9).

Поставянето на диагнозата не представлява трудност. Анамнестичните данни в болшинството от случаите са достатъчни. Допълнителни указания ни дават оцветяването на засегнатите тъкани - алкалите и оцетната киселина дават беловато оцветяване, азотната киселина- жълтеникаво, солната и сярната киселини - кафяво. Установява се оток на увулата, небните дъги, епиглотиca, ариобластта. Не рядко се улавя характерна миризма от устата или повърнатите материи на болния. При съмнителни случаи винаги може с лакмусова хартия да се провери $\mathrm{pH}$ на повърнатите материи. Като задължително изследване освен ПКК и сърдечно-съдовият статус спада и рентгенологичното изследване на хранопровода с водноразтворим контраст. Ендоскопичното изследване на хранопровода, особено при деца, непосредствено след инцидента дава значителна и ценна информация на специалиста, но крие значителен риск за пациента и е желателно да се проведе само от специалист- ендоскопист в тази област в оборудвано за целта клинично звено, 2 напр. Детска хирургична клиника. Но при наличието на новите рентгенологични методи за изследване на хранопровода лекарят трябва да има сериозни основания, освен личното си любопитство, да назначи едно такова рисково остро изследване, каквото е езофагоскопията, без след това да последват лечебни мероприятия. При всички случаи, вкл. и на перфорации, рентгенологичните методи ни дават напълно задоволителни и комплексни резултати $(1,6$, $8,9,10)$. Лекарят задължително трябва да се информира за мотивите за поемане на корозивният агент, защото това ще го ориентира в много отношения - количеството на погълнатото вещество, ако е суицидиум - евентуалното му повторение под друга форма в лечебното заведение, налице може да са и някои проблеми от съдебно-медицински характер. Поведението на лекаря при острото изгаряне на хранопровода е много важен момент. Значителен брой от болните загиват в първите часове на инцидента, като общата смъртност, според различни автори, е от 26 до $50 \%(2,3,13)$. По наши данни тя е около $44 \%$ (9). Лечебните мероприятия се делят на такива на мястото на инцидента и такива след постьпване в лечебното заведение. Непосредствено след злополуката, най-често в дома на пострадалия, се повежда борба за неутрализация на корозивното вещество, като при основи се дава да пие разреден оцет (100 г/л вода), сок от лимон, винена или лимонена киселина. При установяване на киселинно отравяне се дава натриев бикарбонат, прясно мляко. При възможност се установява $\mathrm{pH}$ на повърнатите материи. Добро средство е белтъчно-водната или млечно - белтъчната смес. Тя се приготвя от белтьците на 2-3 сурови яйца и 300-400 мл. Вода или мляко. Тази смес, приготвена в количество 3-4 литра намалява корозивният ефект , образувайки с поетата отрова албуминати $(11,12)$.

В България е възприета тактиката тази пациенти да се хоспитализират незабавно в токсикологичните отделения или ОАРИЛ на болниците. Задължително се започва със стомашни промивки, борба със шока, сърдечно-съдовата слабост, интоксикационните прояви. При наличие на прясно кървене от храносмилателния тракт, сърдечна декомпенсация II-III степен, хипертония над 180 мм $\mathrm{Hg}$, апнея, остър хирургичен корем, стомашните промивки са противопоказани. Задължително се прави рентгенологично изследване на хранопровода с водно разтворим 
контраст. Ако пациентът е в кома, промивките на стомаха се правят след интубацията.

Обективно след 10 ден състоянието на пациента се стабилизира, той бързо се подобрява, а след 15 ден започва да се храни през устата, т.е.настьпва периодът на т. нар. „мнимо благополучие“", когато пациентът, а нерядко и лекарят, са решили, че е настьпило трайно оздравяване. Този период продължава до към 30-40 ден, когато дисфагичните оплаквания започват бързо да прогресират до пълна обтурация на хранопровода. В този период се формират и т.нар. корозивни хипофарингеални мембрани.

Следователно, 15 - 20 ден е периодът, когато пациентьт следва да се насочи, без никакви изключения, към ендоскопичните звена на УНГ отделенията на Районните болници или направо за хоспитализация към УНГ клиника на МБАЛ „Царица Йоанна“ - София за започване на консервативното лечение на хроничния корозивен езофагит - дилатация с различни методики на формиращите се стриктури на хранопровода В момента, на фона на една здравна реформа, налагаща като основна фигура домашния лекар, трябва още веднъж да припомним възприетата в България доктрина за консервативното лечение на хроничния корозивен езофагит. Твърде много нарастна броят на българските лекари, които се сбльскват с това заболяване и отрицателните резултати от недобрата им или липсваща подготовка в тази област са налице - не насочване или късно насочване пациентите за бужиране, отказване на талони за консултация при специалисти, отказване на талони за изследвания, разкарването им по различни хирургии и пр. Разкъсаха се формираните цяло столетие връзки между големите болници в страна за етапното лечение на това заболяване. Особено е тревожен въпросът с организацията на лечение на детския контингент. Пациенти с пресни изгаряния на хранопровода не бива да бъдат хоспитализирани в УНГ отделения, а децата - в детски отделения, където липсват кадрови и материални условия за незабавно започване на специализирано лечение. През последните 4 - 5 години наблюдаваме увлечение на някои лекари с по-малко опит, в провеждането на „контролна езофагоскопия“ с флексибелен езофагоскоп на 10 ден от началото на заболяването - това е периодът на демаркация и най-голям леталитет (9). Това говори за слабата им подготовка и липсата на клиничен
МБ оториноларингология

опит, безсмислено е като манипулация и създава реален риск за живота на пациента и служи само за удовлетворяване на личното любопитство на лекуващия лекар - честите подкожни емфиземи по шията, фебрилните състояния след тази „контрола“ (особено когато химическият агент е уточнен), говорят за нарушение на цялостта на хипофаринкса и хранопровода, влошават състоянието на болния и удължават периода, след който може да се започне успешно бужиране. За това спомагат и писанията на сьмнителни специалисти без опит, които даже отричат неутрализацията на попадналите в организма агенти в острия период и въобще не познаващи възможностите и методологията на консервативното лечение на корозивните стриктури на хранопровода - дилатацията с различни методи - бужиране с хранопроводни бужове, „бужиране без край“, дилатация с ендоназален дилататор въведена от Цолов. Нашите резултати в тази дейност са окуражаващи, върнали сме в семействата им десетки граждани,деца и възрастни, спестили сме им езофагоколопластиката, сьпроводен със значителен леталитет и погльщащ много средства.

Провеждането на езофагоскопия е наложително и задължително след 15 - 20 ден, най-добре под обща анестезия, задължително с ригиден езофагоскоп и поне 2 дни след провеждането на рентгеновото изследване на хранопровода, и то от оториноларинголози-ендоскописти с дългогодишна практика. Самото бужиране се провежда само в легнало положение и то задължително под контрола на езофагоскопната тръба, с местна или обща анестезия. „Бужирането“ в седнало положение, без анестезия и премедикация, нерядко в коридора, е несериозно и безрезултатно и компрометира самият метод на лечение. Пьрвоначално бужиране следва да се прави всеки ден. След постигане на максималния номер - № 30 по Шариер, тези периоди почват да се раздалечават като се намира интервалът, в който пациентьт трябва да се явява на бужиране. Не трябва да се забравя, че това е заболяване за цял живот, дефинитивно, че се касае за инвалидизация и личният лекар следва да представи пациента пред ТЕЛК за определяне на група инвалидност.

В заключение трябва още веднъж да препоръчаме на уважаемата медицинска колегия някои основни етапи от лечението на изгарянията на 
хранопровода с киселини и основи: непосредствено след инцидента децата следва да попаднат в токсикологични, реанимационни отделения или клиники по детска хирургия, възрастните пациенти задължително да се хоспитализират в токсикологични или реанимационни отделения. И в двата случая след 15-20 ден пациентите, деца и възрастни, следва да се консултират със специализираните УНГ-клиники относно възможностите за консервативно лечение.

\section{Литература}

1. Белинов, Ст.: Болести на ухото,носа и гърлото. София, 1936, 306-314.

2. Белый, И., Д. Чухриенко, Д. Сердюк: Бытовые химические ожоги пищевода. Киев, 1980, 3-26.

3. Дончев, Хр.: Диагностично-терапевтичен наръчник по оториноларингология, София, 1976, 235-237.

4. Дончев, Хр., Ил. Йовчев: Срокове за образуване на стесненията на хранопровода при изгаряне с корозивни вещества. Оториноларингологични страници, год. II, 3-4, 1995, 12-18.

5. Кабакчиев, Г.: Детска оториноларингология, София, 1988, 204207.

6. Павлов, Вл.: Учебник по ушно-носно-гърлени болести. София, 1988, 214-217.

7. Сотиров, Н.: Спешна помощ в оториноларингологията. София, 1981, 90-98.

8. Цолов, Ц.: В учебник „Оториноларингология“, София, Знание ЕООД, 1998, 301-312.

9. Цолов, Ц., В. Павлов, Д. Иванов и кол.: Лечебна тактика при острите изгаряния на хранопровода. Оториноларингология, IV, 2000, 2, 24-34.

10. Belinoff, S., J. Terracol: Les maladies de l'oesophage.Paris, 1938, 389-434.

11. Brette, M. D., Aidan D., Monteil J. K.: Brulures de l'oesophage: indications therapeutiques. Encycl. Med. Chir. Oto-RhinoLaryngologie, 1994, 20-820-A10, 9.

12. Marie J. P., Deshedin D., De Sevin E., Andrieu-Guitrancourt J.: Prise en charge des brulures caustiques de l'oesophage chez l'enfant. Ann. Pediatr., Paris, 1992, 39, 8, 495-500.

13. Polonovski, J.M.: Brulures caustiques de l'oesophage. Dans: “ORL de l'enfant, Flamarion, Paris, 1996, 253-257. 